\title{
Evaluation of a Soil Decompaction and Amendment Process for Urban Trees
}

\author{
Kelby Fite, E. Thomas Smiley, John Mclntyre, and Christina E. Wells
}

\begin{abstract}
Researchers investigated the effects of a soil decompaction and amendment process (AFM) and its individual components (air tillage, fertilizer, and mulch) on soil properties at four urban sites: Anderson, South Carolina; Boston, Massachusetts; Myrtle Beach, South Carolina; and Pittsburgh, Pennsylvania, U.S. At each site, 50 red maples (Acer rubrum) were growing on compacted and/or nutrient-poor soils whose pre-treatment bulk densities ranged from 1.14 to $1.74 \mathrm{~g} / \mathrm{cm}^{3}$. Treatments were applied in the autumn and winter of 2005-2006, and measurements were taken through the end of 2008. The AFM treatment significantly reduced soil strength relative to control at all sites in 2006. There were significant treatment $\times$ location interactions in all years, with higher bulk density sites (Anderson and Myrtle Beach) showing the greatest magnitude and duration of response. The AFM and mulch treatments generally increased soil organic matter content, while air tillage alone significantly lowered soil organic matter content in Pittsburgh. At most sites, the AFM treatment was more effective than surface fertilizer application at improving soil fertility. AFM and mulched plots had significantly higher soil water content than other plots during periods of summer drought. Overall, AFM was effective in improving soils beneath established trees, and mulching was the most beneficial of the individual treatments.

Key Words. Acer rubrum L.; Air Tillage; Decompaction; Fertilizer; Mulch; Organic Matter; Soil Strength; Urban Soils.
\end{abstract}

Urban soils are a challenging medium for tree root growth. Construction activities and soil compaction create a belowground environment that is resistant to root penetration, low in fertility, and prone to extremes of both drought and anoxia (Alberty et al. 1984; Day and Bassuk 1994; Watson et al. 1996). Loss of topsoil and removal of fallen leaves limit the development of the upper organic horizon in which fine roots typically proliferate (Fraedrich and Ham 1982; Harris et al. 2004).

Successful strategies for the decompaction and amendment of urban soils would be useful to homeowners, municipalities, and tree care companies. Unfortunately, few effective options exist. While soil compaction can be offset by mechanical tillage prior to planting, traditional tilling would cause significant root damage if performed beneath the canopy of established trees.

A variety of pneumatic injection devices have been developed to physically fracture compacted soils with high-pressure air or nitrogen (Smiley et al. 1990). Such injections have seldom improved soil physical properties, and results have been highly dependent on location and soil type (Smiley et al. 1990; Rolf 1994; Smiley 1994; Smiley 2001). Air injection treatments had no effect on trunk diameter growth in four tree species (Smiley 1994), and similar results were reported for shoot growth, plant height, and aboveground dry mass in five tree species (Rolf 1994).

Vertical and radial mulching represent another approach to soil improvement. Vertical mulching involves drilling a series of shallow holes in the root zone and filling them with compost, perlite, fertilizers, or other materials. Few studies have examined its benefits. In one report, roots avoided the perlite-filled holes (Ka- lisz et al. 1994); in a second report, tree growth responded as well to empty holes as it did to those filled with fertilizer (Smith 1978).

Replacing larger soil volumes in radial trenches, pits, or numerous small holes has shown greater promise. Research by Watson et al. (1996) and Watson (2002) reported deeper rooting and denser root growth in the amended fill soil of radial trenches, as well as larger growth rings following soil replacement. These results suggest that the magnitude of the replaced soil volume may be critical in determining the success of the treatment.

Recently, a process designed to decompact a portion of the root zone while simultaneously incorporating organic matter and fertilizer into the soil was tested. Reported here are changes in soil chemical and physical properties associated with the decompaction and amendment process (AFM) and its individual components (air tillage, fertilizer, and mulch) beneath red maples (Acer rubrum L.) at four urban locations. Specific objectives of the study were 1) to test whether soil strength, organic matter, fertility, and water content would be improved by the AFM treatment, and 2) to determine whether any individual component produced results similar to the full process.

\section{MATERIALS AND METHODS}

\section{Site Characterization}

The study was conducted on 200 red maple trees at four locations: Anderson, South Carolina (city park and recreation facility); Myrtle Beach, South Carolina (street tree plantings); 
Boston, Massachusetts (college campus); and Pittsburgh, Pennsylvania (golf course) in the United States. Soils ranged from sand with a bulk density of $1.74 \mathrm{~g} / \mathrm{cm}^{3}$ in Myrtle Beach to loam with a bulk density of $1.25 \mathrm{~g} / \mathrm{cm}^{3}$ in Pittsburgh (Table 1). At Myrtle Beach and Anderson, soils were approaching the growth limiting bulk density for their texture, and it is likely that root penetration was impaired at these sites (Daddow and Warrington 1983). At Boston and Pittsburgh, bulk densities were lower and less likely to physically restrict root growth.

Prior to the experiment, composite soil samples were collected from the upper $15 \mathrm{~cm}$ of soil beneath 6-8 trees at each site and analyzed by A\&L Analytical Laboratory (Memphis, Tennessee, U.S.) to determine soil $\mathrm{pH}$ and mineral nutrient concentrations. Nutrient data were used to create a prescription fertilizer program for each site that complied with ANSI A300 standards (Table 2).

\section{Experimental Design and Treatment Application}

Five treatments [mulch $(\mathrm{M})$, fertilizer $(\mathrm{F})$, air tillage $(\mathrm{A})$, the full decompaction and amendment process (AFM), and control (C)] were applied to ten replicate trees at each site. A completely randomized experimental design was used in Boston. A randomized complete block design was used to control for within-site variability at Anderson, Myrtle Beach, and Pittsburgh. Treatments were applied in August 2005 in Boston, November 2005 in Anderson, November 2005 in Myrtle Beach, and February 2006 in Pittsburgh.

At least 14 days prior to treatment, the area surrounding all trees was treated with Roundup Pro herbicide (Monsanto Company, St. Louis, Missouri, U.S.) in a $1.5 \mathrm{~m}$ diameter ring to eliminate competing vegetation. Weed control was maintained throughout the experiment with additional herbicide applications as needed.

In Boston, an extensive turf thatch layer remained after herbicide application. To permit air tillage, thatch was removed to a depth of $3 \mathrm{~cm}$ from beneath A and AFM trees using a Ryan ${ }^{\circledR}$ Jr. sod cutter (Jacobsen, Schiller, Wisconsin, U.S.). Some tree fine roots were likely damaged in this process, and trees from other treatment groups did not experience this damage.

Soils receiving the $\mathrm{M}$ treatment were mulched to a depth of $5-7.5 \mathrm{~cm}$ in a $1.5 \mathrm{~m}$ radius around the trunk using $0.45 \mathrm{~m}^{3}$ of bagged, shredded hardwood mulch. The specific mulch products differed among sites, based on local availability. Soils receiving the $\mathrm{F}$ treatment were fertilized with the prescribed materials (Table 2) applied to the soil surface as granular products or drenches within a $1.5 \mathrm{~m}$ radius around the trunk. Soils receiving the A treatment were air-tilled in a $1.5 \mathrm{~m}$ radius and

Table 1. Soil particle size distribution, bulk density (BD), and estimated growth-limiting bulk density (GLBD) for each study site.

\begin{tabular}{|c|c|c|c|c|c|c|}
\hline Site & $\begin{array}{l}\text { Soil type } \\
(\%)\end{array}$ & $\begin{array}{l}\text { Sand }^{y} \\
(\%)\end{array}$ & $\begin{array}{l}\text { Silt } \\
(\%)\end{array}$ & $\begin{array}{l}\text { Clay } \\
\left(\mathrm{g} / \mathrm{cm}^{3}\right)\end{array}$ & $\begin{array}{l}\mathrm{BD} \\
\left(\mathrm{g} / \mathrm{cm}^{3}\right)\end{array}$ & GLBD \\
\hline Anderson, South Carolina & sandy clay loam & 55 & 19 & 26 & $1.41 \pm 0.02$ & 1.6 \\
\hline Myrtle Beach, South Carolina & sand & 93 & 3 & 4 & $1.74 \pm 0.04$ & 1.8 \\
\hline Pittsburgh, Pennsylvania & loam & 32.9 & 44.7 & 22.4 & $1.25 \pm 0.03$ & 1.5 \\
\hline
\end{tabular}

${ }^{z}$ Threshold bulk density above which roots can no longer penetrate the soil (Daddow and Warrington 1983). Root growth is impaired as BD approaches the GLBD. ${ }^{y} N=2-3$ for particle size distribution and $N=50$ for bulk density at each site.

Table 2. Fertilizer products applied to $7.1 \mathrm{~m}^{2}$ soil area around the base of each tree receiving the AFM or $F$ treatment. Products and rates were selected for each site based on pre-treatment soil tests. In Anderson, trees were present in three separate portions of the Civic Center complex, each of which received slightly different fertilizer rates.

\begin{tabular}{|c|c|c|c|c|c|}
\hline $\begin{array}{l}\text { Product } \\
\text { Boost Granular } \\
(24-7-7,6 \% \mathrm{~S}, 1 \% \mathrm{Ca} \text {, } \\
0.1 \% \mathrm{Fe}, 0.05 \% \mathrm{Cu}, \\
0.05 \% \mathrm{Zn})\end{array}$ & $\begin{array}{l}\text { Manufacturer } \\
\text { F.A. Bartlett Tree } \\
\text { Expert Co. } \\
\text { Stamford, Connecticut }\end{array}$ & $\begin{array}{l}\text { Anderson } \\
375-470 \mathrm{~g}\end{array}$ & $\begin{array}{l}\text { Boston } \\
1.3 \mathrm{~kg}\end{array}$ & $\begin{array}{l}\text { Myrtle Beach } \\
565 \mathrm{~g}\end{array}$ & $\begin{array}{l}\text { Pittsburgh } \\
262 \mathrm{~g}\end{array}$ \\
\hline $\begin{array}{l}\text { Manganese chelate } \\
(5 \% \mathrm{Mn}, 2 \% \mathrm{~S})\end{array}$ & $\begin{array}{l}\text { Growth Products, Ltd. } \\
\text { White Plains, New York }\end{array}$ & & & $79 \mathrm{ml}$ & $300 \mathrm{ml}$ \\
\hline $\begin{array}{l}\text { Epsom salt } \\
\left(100 \% \mathrm{MgSO}_{4}\right)\end{array}$ & $\begin{array}{l}\text { Top Co Associates } \\
\text { Skokie, Illinois }\end{array}$ & $0-265 \mathrm{~g}$ & & $455 \mathrm{~g}$ & $169 \mathrm{~g}$ \\
\hline Pelletized dolomitic lime & $\begin{array}{l}\text { ASC Mineral Processing } \\
\text { Allerton, Illinois }\end{array}$ & $0-1.4 \mathrm{~kg}$ & & & \\
\hline $\begin{array}{l}\text { Pelletized gypsum } \\
(20 \% \mathrm{Ca}, 16 \% \mathrm{~S})\end{array}$ & $\begin{array}{l}\text { ASC Mineral Processing } \\
\text { Allerton, Illinois }\end{array}$ & & & & $3.5 \mathrm{~kg}$ \\
\hline $\begin{array}{l}\text { Disper-Sul } \\
(80 \% \mathrm{~S}, 3.5 \% \mathrm{Fe}, \\
1.5 \% \mathrm{Mn})\end{array}$ & $\begin{array}{l}\text { Martin Resources, Inc. } \\
\text { Odessa, Texas }\end{array}$ & & & & $1.1 \mathrm{~kg}$ \\
\hline
\end{tabular}


a 15-20 cm depth using an air tool (Air Spade ${ }^{\circledR}$ series 2000, Concept Engineering Group, Verona, Pennsylvania, U.S.). Control trees received no amendment or tillage treatment, but were maintained with a $1.5 \mathrm{~m}$ radius vegetation-free zone.

The AFM treatment began with air tillage, as previously described. Soils were then amended with $0.28 \mathrm{~m}^{3}$ of composted cow manure and the prescription fertilizer materials from the $\mathrm{F}$ treatment. Amendments were applied to a $1.5 \mathrm{~m}$ radius and incorporated into the loosened soil profile with the air tool. Finally, amended soil received a mulch layer as described for the $\mathrm{M}$ treatment. It is important to note that compost was added as part of the full AFM process only and was not present in any individual treatment. Specific compost products differed among sites, depending on local availability.

Immediately after treatment application, $30 \mathrm{~L}$ of irrigation was applied to the $1.5 \mathrm{~m}$ treatment radius of all trees in Boston and Myrtle Beach. Boston trees received identical irrigation applications at one and three weeks post-treatment due to dry weather conditions.

Because of long-term seasonal drought at the Anderson site, water applications were required to prepare the soil for air tillage. Anderson trees received $106 \mathrm{~L}$ of water injected approximately $15 \mathrm{~cm}$ beneath the soil surface. Trees receiving $\mathrm{A}$ and AFM treatments were given split applications, with half of the water injected prior to treatment and half as a drench following treatment. M-, F-, and C-treated trees received the full irrigation amount after treatment application.

In Pittsburgh, five centimeters of snow fell on the day following treatment application, making post-treatment irrigation unnecessary. No further irrigation or fertilization was supplied at any site over the course of the experiment.

\section{Bulk density and soil strength measurements}

Pre-treatment soil bulk densities were measured by collecting a $5.8 \mathrm{~cm}$ diameter soil core from beneath each tree, approximately $0.75 \mathrm{~m}$ from the trunk. Cores were trimmed to $7.6 \mathrm{~cm}$ in length, and leaf litter and organic matter were removed from the top. The cores were stored at $5^{\circ} \mathrm{C}$ in waxlined paper bags for less than one week before processing. Cores were transferred to aluminum trays, dried for seven days to constant weight at $65^{\circ} \mathrm{C}$, and weighed to calculate dry bulk density $\left(\mathrm{g} / \mathrm{cm}^{3}\right)$. These data are reported in Table 1 and represent initial soil bulk densities at the sites.

Bulk density measurements were not made after treatment application. Loosened, mulched, and/or amended soils have a tendency to compress during coring, causing bulk density measurements to overestimate true bulk density (Tan 1996). Instead, a Clegg impact hammer with a $2.5 \mathrm{~kg}$ weight (Lafayette Instruments Company, Lafayette, Indiana, U.S.) was used to estimate soil strength. Hammer measurements were made yearly at each site. Mulch, if present, was temporarily removed from the soil surface prior to measurement.

The Clegg hammer drops a weighted accelerometer from a standard height and measures its deceleration upon impact with the soil surface. This measurement is reported as a Clegg Impact Value (CIV). Soils with high CIVs have greater unconfined compressive strength, and therefore present greater mechanical impedance to root growth (Pabin et al. 1998; Janoo et al. 1999; Waltz et al. 2000). Bulk density and soil strength are positively correlated, although the spe- cific relationship between them differs with soil water content and soil type (Mirreh and Ketcheson 1972; Sojka et al. 2001).

\section{Soil Nutrient and Organic Matter Measurements}

Composite soil samples from three locations within the treated radius of each tree were collected in spring 2006 and 2007 for soil nutrient analysis. Samples were mailed overnight to the Clemson University Agricultural Services Laboratory for soil $\mathrm{pH}$, CEC, organic matter, and mineral nutrient analyses (Moore 2010).

\section{Soil Water Content Measurement}

In Anderson, a time domain reflectometry probe $(20.5 \mathrm{~cm}$ length) was placed horizontally in the soil beneath one tree from each treatment (five probes total). Volumetric soil moisture content was measured weekly during the growing season using the TRASE time domain reflectometry system I (Soil moisture Equipment Corp., Santa Barbara, California, U.S.). Data from the mulched treatments (M and AFM) and the unmulched treatments (A, F, and control) were combined for analysis.

\section{Statistical Analyses}

The effects of treatment, location, and their interactions on soil parameters were analyzed using a general linear model. Mean separations were performed with Fisher's least significant difference (SAS PROC GLIMMIX, SAS version 9.1; SAS Institute, Cary, North Carolina, U.S.). The effects of treatment and time on soil moisture content in Anderson were analyzed using a repeated measures model in GLIMMIX, and mean separations were performed as previously described. Data met normality and equality of variance assumptions.

\section{RESULTS}

\section{Soil Strength}

The AFM treatment significantly reduced soil strength relative to control at all sites in 2006 (Figure 1). There were significant treatment $\times$ location interactions in all years, with the higher bulk density sites (Anderson and Myrtle Beach) showing the greatest magnitude and duration of response. The A and $\mathrm{M}$ treatments also reduced soil strength in Anderson and Myrtle Beach, although their effects were less pronounced.

\section{Soil Organic Matter}

The effect of treatment on soil organic matter also differed across sites (Figure 2). Pittsburgh had the highest percentage of initial soil organic matter of any site (7.4\%). None of the treatments increased soil organic matter above control levels at this site, but the A treatment significantly decreased levels. Anderson and Boston had initial soil organic matter percentages of $4.2 \%$ and $6.2 \%$, respectively. At these sites, the AFM and $\mathrm{M}$ treatments significantly increased soil organic matter, while the A treatment had no effect. The sandy soil of Myrtle Beach had extremely low initial soil organic matter (1\%). The AFM treatment was the only treatment to increase soil organic matter at this site; the effect lasted only through 2007. 


\section{Soil Nutrient Levels}

The A treatment had little effect on soil nutrient concentrations (Table 3; Table 4). The M treatment occasionally altered individual nutrients at specific sites [e.g., increased Calcium (Ca) and Magnesium (Mg) in Boston and Anderson, decreased $\mathrm{NO}_{3}-\mathrm{N}$ in Pittsburgh)]. The AFM treatment increased levels of two soil nutrients in Myrtle Beach and Pittsburgh, 4-5 nutrients in Anderson, and 6-7 nutrients in Boston, depending on the year (Table 3; Table 4). By contrast, the fertilizer-only treatment increased levels of 2-3 soil nutrients at Myrtle Beach, 1-3 nutrients in Pittsburgh, 0-1 nutrients in Anderson, and zero nutrients in Boston. Because the specific prescription fertilizer materials differed among sites (see Table 2), each site will be discussed separately.

In Anderson, AFM increased soil levels of five nutrients in 2007 [Phosphorus (P), Potassium (K), Zinc ( $\mathrm{Zn})$, Copper $(\mathrm{Cu})$, and $\mathrm{Mg}]$ and four nutrients in $2008(\mathrm{P}, \mathrm{K}, \mathrm{Mg}$, and $\mathrm{Zn})$. In contrast, broadcast application of the same fertilizer materials to the root zone without the organic matter addition $(\mathrm{F}$ treatment) only increased K in 2007 and had no effect in 2008.

In Boston, AFM increased soil levels of seven nutrients in 2007 [ $(\mathrm{P}, \mathrm{K}, \mathrm{Ca}, \mathrm{Mg}, \mathrm{Zn}$, Manganese $(\mathrm{Mn})$, and Boron (B)] and six nutrients in 2008 (P, Ca, Mg, Zn, Mn, and $\mathrm{B})$. AFM decreased $\mathrm{Cu}$ in 2007. In contrast, the F treatment had no effect on soil nutrients in Boston.

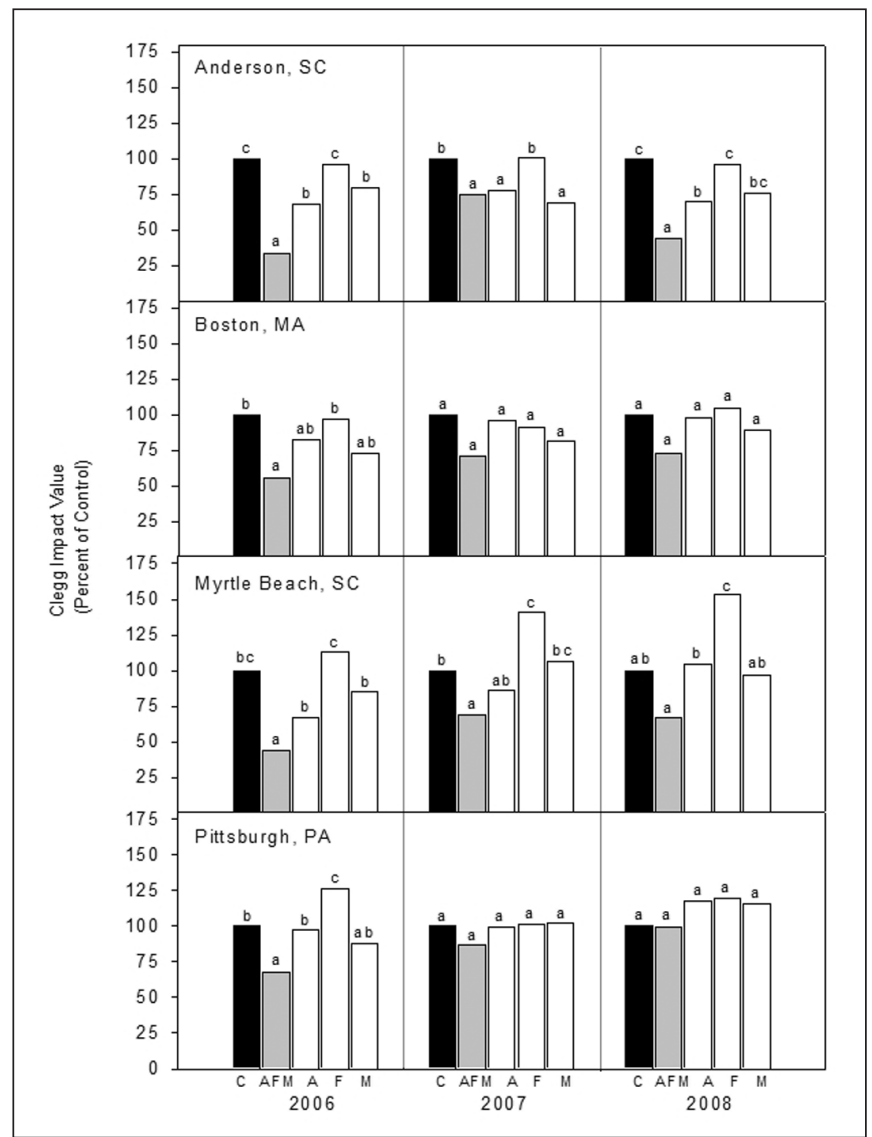

Figure 1. Soil strength measured with Clegg impact hammer at individual sites in the spring of 2006, 2007, and 2008. Within a site and year, treatment means with different letters are significantly different (Fisher's LSD $P<0.05 ; \mathrm{N}=10$ for each bar).
In Myrtle Beach, whose sandy soil had the lowest pre-treatment nutrient levels, AFM increased levels of two nutrients in 2007 and 2008 (Mg and $\mathrm{Mn}$ ). In 2008, AFM also decreased levels of soil P. The F treatment increased levels of three nutrients in 2007 ( $\mathrm{Zn}$, $\mathrm{Mn}$, and $\mathrm{Cu}$ ) and two nutrients in 2008 ( $\mathrm{Zn}$ and $\mathrm{Mn}$ ).

In Pittsburgh, which had the highest pre-treatment soil nutrient levels, AFM increased one nutrient in 2007 (P) and two nutrients in 2008 ( $\mathrm{P}$ and Mn). AFM, F, and M also decreased Nitrate Nitrogen $\left(\mathrm{NO}_{3}-\mathrm{N}\right)$ in 2007. Surprisingly, the $\mathrm{F}$ treatment decreased levels of four nutrients in $2007\left(\mathrm{NO}_{3}-\right.$ $\mathrm{N}, \mathrm{K}, \mathrm{Mg}$, and $\mathrm{B}$ ) and $2008(\mathrm{~K}, \mathrm{Mg}, \mathrm{Zn}$, and $\mathrm{B})$. There was also a marked lowering of soil $\mathrm{pH}$ relative to control in the $\mathrm{F}$ treatment (4.8, versus 6.1 for control) and an increase in $\mathrm{Mn}$ and $\mathrm{Cu}$. It is thought that sulfur may have been overapplied in the $\mathrm{F}$ treatment, resulting in markedly decreased soil $\mathrm{pH}$ and concomitant changes in nutrient availability.

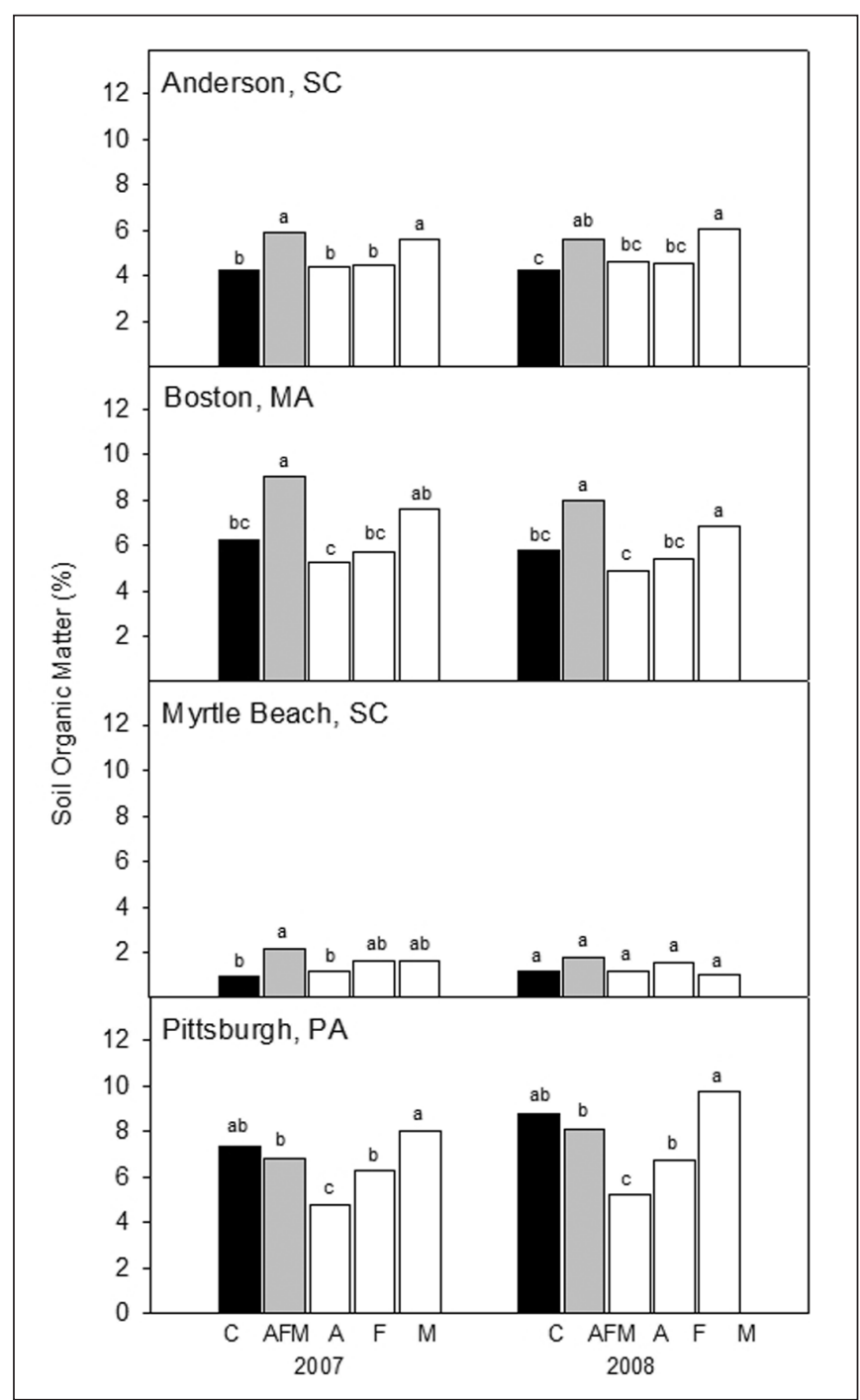

Figure 2. Percent soil organic matter at individual sites in spring 2007 and 2008. Within a site and year, treatment means with different letters are significantly different (Fisher's LSD $P<0.05$; N $=10$ for each bar). 


\section{Soil Volumetric Water Content}

Soil volumetric water content was measured at the Anderson site only; data from the two mulched treatments (AFM and $\mathrm{M}$ ) and the three unmulched treatments (A, F, and control) were combined for analysis.

Mulched soils had significantly higher volumetric water content than unmulched soils throughout the experiment $(P<0.0001$ treatment main effect; repeated measures model in SAS PROC GLIMMIX). Averaged across all sampling dates, mulched soils had a water content of $30.8 \pm$ $6.9 \%$, while unmulched soils had a water content of $24.7 \pm$ $6.7 \%$. Differences in water content on individual dates appeared during periods of prolonged drought, such as the second half of the 2007 and 2008 growing seasons (Figure 3).

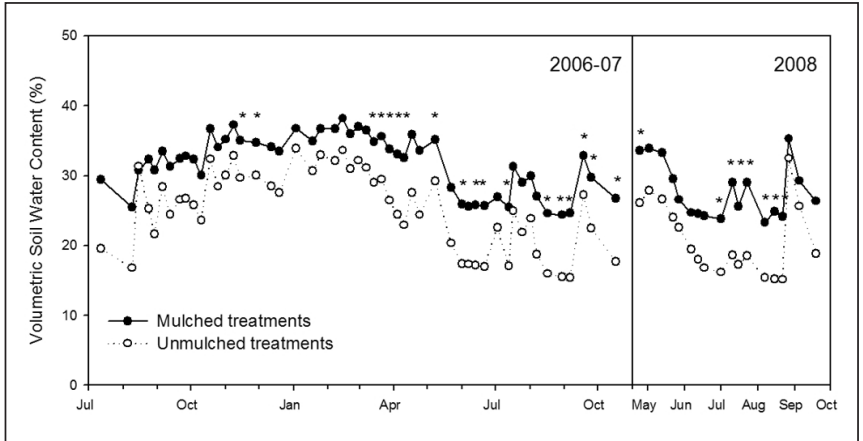

Figure 3. Volumetric soil moisture content measured by time domain reflectometry in Anderson, South Carolina. Asterisk $\left(^{*}\right)$ Denotes a significant difference between mulched and unmulched treatments on individual dates (Fisher's LSD $P<0.05$; $N=2$ for mulched and $\mathrm{N}=3$ for unmulched).

\section{DISCUSSION}

\section{Soil Strength}

In general, the largest and longest lasting reductions in soil strength were associated with the full AFM treatment. Air-tilled (A) soils recompacted to pre-treatment levels within three years at all sites except Anderson. The addition of organic matter and mulch following air tillage in AFM appeared to minimize recompaction, perhaps by holding open the newly-loosened soil structure.

Reductions in soil strength were minimal and transient at sites with low initial bulk densities. Boston and Pittsburgh soils had relatively low bulk densities, and at both sites the significant effect of AFM on soil strength persisted for only one year. These transient reductions are unlikely to have had a long-term impact on tree performance.

The effect of AFM on soil strength persisted for multiple years at the heavily compacted Myrtle Beach and Anderson sites. In particular, the three-year, $25 \%$ to $66 \%$ soil strength reduction in Anderson's heavy clay is likely to be ecologically relevant. While few published comparisons of bulk density and CIV measurements exist, one study indicates that $25 \%$ to $40 \%$ reductions in CIV were associated with $28 \%$ to $35 \%$ reductions in bulk density on sporting fields (Department of Environment and Climate Change 2007).

\section{Soil Organic Matter}

In general, the $\mathrm{M}$ and $\mathrm{AFM}$ treatments were equally effective at increasing soil organic matter content despite the fact that AFM-treated soils also contained added compost. If increasing organic matter were the primary management goal, mulching appeared to be just as effective as the more time-consuming and expensive AFM process.

Table 3. Soil pH and nutrient concentrations beneath red maple (Acer rubrum) trees at four urban sites in the eastern United States in spring 2007. Within a site and column, means following by different letters are significantly different (SAS PROC GLIMMIX, Fisher's LSD P < 0.05). For treatment descriptions, see Materials and Methods.

\begin{tabular}{|c|c|c|c|c|c|c|c|c|c|c|c|}
\hline Site & Treatment & $\mathrm{pH}$ & $\begin{array}{l}\mathrm{NO}_{3} \\
(\mathrm{ppm})\end{array}$ & $\begin{array}{l}\mathrm{P} \\
\text { (kg/ha) }\end{array}$ & $\begin{array}{l}\mathrm{K} \\
\text { (kg/ha) }\end{array}$ & $\begin{array}{l}\mathrm{Ca} \\
(\mathrm{t} / \mathrm{ha})\end{array}$ & $\begin{array}{l}\mathrm{Mg} \\
\text { (kg/ha) }\end{array}$ & $\begin{array}{l}\mathrm{Zn} \\
\text { (kg/ha) }\end{array}$ & $\begin{array}{l}\mathrm{Mn} \\
\text { (kg/ha) }\end{array}$ & $\begin{array}{l}\mathrm{Cu} \\
\text { (kg/ha) }\end{array}$ & $\begin{array}{l}\text { B } \\
(\mathrm{kg} / \mathrm{ha})\end{array}$ \\
\hline \multirow[t]{5}{*}{ Anderson } & $\mathrm{C}$ & $6.1 \mathrm{bc}$ & $1.3 \mathrm{a}$ & $7.3 b$ & $182.2 \mathrm{c}$ & $1.2 \mathrm{~b}$ & $132.8 \mathrm{c}$ & $2.6 \mathrm{~b}$ & $45.7 \mathrm{a}$ & $2.4 \mathrm{~b}$ & $0.7 \mathrm{~b}$ \\
\hline & AFM & $6.7 \mathrm{a}$ & $1.2 \mathrm{a}$ & $22.4 \mathrm{a}$ & $306.4 \mathrm{a}$ & $1.9 \mathrm{ab}$ & $355.5 \mathrm{a}$ & $6.8 \mathrm{a}$ & $60.0 \mathrm{a}$ & $4.9 \mathrm{a}$ & $1.3 \mathrm{ab}$ \\
\hline & A & $6.2 b c$ & $0.7 \mathrm{a}$ & $6.9 \mathrm{~b}$ & $212.1 b c$ & $1.3 \mathrm{~b}$ & $141.5 b c$ & $2.5 b$ & $45.7 \mathrm{a}$ & $2.9 \mathrm{ab}$ & $0.6 b$ \\
\hline & $\mathrm{F}$ & $6.0 \mathrm{c}$ & $1.0 \mathrm{a}$ & $9.2 \mathrm{~b}$ & $204.1 b$ & $1.2 \mathrm{~b}$ & $171.6 \mathrm{bc}$ & $2.6 b$ & $54.7 \mathrm{a}$ & $2.7 \mathrm{~b}$ & $0.6 b$ \\
\hline & M & $6.5 \mathrm{ab}$ & $1.2 \mathrm{a}$ & $5.0 \mathrm{~b}$ & $233.3 b c$ & $2.2 \mathrm{a}$ & $180.0 \mathrm{~b}$ & $4.0 \mathrm{~b}$ & $56.2 \mathrm{a}$ & $2.0 \mathrm{~b}$ & $1.6 \mathrm{a}$ \\
\hline \multirow[t]{5}{*}{ Boston } & $\mathrm{C}$ & $5.7 b$ & $2.8 \mathrm{ab}$ & $96.7 \mathrm{~b}$ & $126.4 b$ & $2.0 \mathrm{~cd}$ & $206.5 \mathrm{c}$ & $10.0 \mathrm{bc}$ & $44.6 b$ & $6.3 \mathrm{a}$ & $0.6 \mathrm{~b}$ \\
\hline & AFM & $6.6 \mathrm{a}$ & $3.3 \mathrm{ab}$ & $268.0 \mathrm{a}$ & $167.1 \mathrm{a}$ & $5.6 \mathrm{a}$ & $364.7 \mathrm{a}$ & $25.6 \mathrm{a}$ & $66.1 \mathrm{a}$ & $3.2 b$ & $1.0 \mathrm{a}$ \\
\hline & $\mathrm{A}$ & $5.8 \mathrm{~b}$ & $4.2 \mathrm{a}$ & $100.7 \mathrm{~b}$ & $121.7 \mathrm{~b}$ & $1.9 \mathrm{~d}$ & $188.6 \mathrm{c}$ & $7.8 \mathrm{c}$ & $36.8 b$ & $6.2 \mathrm{a}$ & $0.4 \mathrm{c}$ \\
\hline & $\mathrm{F}$ & $6.0 \mathrm{~b}$ & $4.1 \mathrm{a}$ & $118.7 \mathrm{~b}$ & $124.1 b$ & $2.4 \mathrm{bc}$ & $215.3 b c$ & $10.9 b c$ & $44.9 \mathrm{~b}$ & $6.3 \mathrm{a}$ & $0.6 \mathrm{~b}$ \\
\hline & M & $5.8 \mathrm{~b}$ & $1.9 \mathrm{~b}$ & $94.0 \mathrm{~b}$ & $115.2 b$ & $2.5 b$ & $239.6 b$ & $12.7 \mathrm{~b}$ & $57.1 \mathrm{a}$ & $3.8 \mathrm{~b}$ & $0.6 b$ \\
\hline \multirow[t]{4}{*}{ Myrtle Beach } & $\mathrm{C}$ & $7.2 \mathrm{ab}$ & $1.9 \mathrm{a}$ & $61.8 \mathrm{ab}$ & $83.2 \mathrm{a}$ & $5.2 \mathrm{a}$ & $101.8 b$ & $3.6 \mathrm{~b}$ & $15.8 \mathrm{~b}$ & $0.7 \mathrm{~b}$ & $0.6 \mathrm{a}$ \\
\hline & AFM & $6.4 b$ & $0.9 \mathrm{a}$ & $53.2 \mathrm{ab}$ & $103.4 \mathrm{a}$ & $6.8 \mathrm{a}$ & $205.0 \mathrm{a}$ & $5.3 b$ & $31.8 \mathrm{a}$ & $0.8 \mathrm{ab}$ & $0.7 \mathrm{a}$ \\
\hline & A & $7.3 \mathrm{ab}$ & $1.6 \mathrm{a}$ & $48.0 \mathrm{~b}$ & $84.7 \mathrm{a}$ & $6.6 \mathrm{a}$ & $134.0 \mathrm{ab}$ & $4.8 b$ & $17.8 \mathrm{~b}$ & $0.8 \mathrm{ab}$ & $0.6 \mathrm{a}$ \\
\hline & $\mathrm{F}$ & $6.2 \mathrm{ab}$ & $1.2 \mathrm{a}$ & $75.4 \mathrm{a}$ & $102.9 \mathrm{a}$ & $6.0 \mathrm{a}$ & $132.7 \mathrm{ab}$ & $9.0 \mathrm{a}$ & $40.3 \mathrm{a}$ & $1.6 \mathrm{a}$ & $0.7 \mathrm{a}$ \\
\hline \multirow[t]{5}{*}{ Pittsburgh } & $\mathrm{C}$ & $6.1 \mathrm{~b}$ & $4.8 \mathrm{a}$ & $97.6 \mathrm{~b}$ & $350.8 \mathrm{ab}$ & $4.3 \mathrm{a}$ & $409.7 \mathrm{a}$ & $11.9 \mathrm{a}$ & $77.4 \mathrm{bc}$ & $1.8 \mathrm{~b}$ & $1.2 \mathrm{bc}$ \\
\hline & AFM & $5.9 \mathrm{~b}$ & $2.0 \mathrm{c}$ & $134.8 \mathrm{a}$ & $383.9 \mathrm{ab}$ & $5.2 \mathrm{a}$ & $406.3 \mathrm{a}$ & $11.9 \mathrm{a}$ & $111.2 \mathrm{~b}$ & $2.0 \mathrm{~b}$ & $1.7 \mathrm{ab}$ \\
\hline & A & $6.3 b$ & $3.9 \mathrm{ab}$ & $117.9 \mathrm{ab}$ & $320.5 b$ & $4.4 \mathrm{a}$ & $467.2 \mathrm{a}$ & $7.7 \mathrm{~b}$ & $67.8 \mathrm{c}$ & $1.8 \mathrm{~b}$ & $1.1 \mathrm{c}$ \\
\hline & $\mathrm{F}$ & $4.8 \mathrm{c}$ & $2.0 \mathrm{c}$ & $88.7 b$ & $243.9 \mathrm{c}$ & $4.8 \mathrm{a}$ & $281.1 \mathrm{~b}$ & $10.5 \mathrm{ab}$ & $168.9 \mathrm{a}$ & $6.2 \mathrm{a}$ & $0.6 \mathrm{~d}$ \\
\hline & M & $6.8 \mathrm{a}$ & $2.7 \mathrm{bc}$ & $107.5 \mathrm{ab}$ & $400.0 \mathrm{a}$ & $5.7 \mathrm{a}$ & $502.2 \mathrm{a}$ & $8.0 \mathrm{~b}$ & $80.9 b c$ & $1.2 \mathrm{~b}$ & $1.8 \mathrm{a}$ \\
\hline
\end{tabular}


These data that confirm Watson's (1988) findings that surface mulch layers can lead to increases in soil organic matter as mulch decomposes. It should be noted that the measurement protocol did not measure the depth distribution of organic matter. The extent to which the mulch-derived organic matter had broken down and penetrated into the soil profile is unknown; it may have been concentrated primarily near the soil surface.

As with soil strength measurements, the degree of organic matter enhancement varied among sites. The two sites with moderate initial levels of organic matter (Boston, 6.2\%; Anderson, 4.2\%) benefited most from the AFM and M treatments. The sites with high (Pittsburgh, 7.4\%) and very low (Myrtle Beach, 0.95\%) levels of organic matter benefited least.

Organic matter appeared to break down very rapidly in the warm, sandy soils of Myrtle Beach: no effects of the AFM or M treatment were visible after 2006. Clearly, mulch would need to be applied frequently at this site to maintain increased levels of organic matter. In Pittsburgh, AFM and M treatments never increased soil organic matter above the already high initial levels.

Interestingly, air tillage (A) alone was associated with a decrease in soil organic matter in the organic-rich Pittsburgh loam (Figure 2). Researchers in this study suspect that air tillage improved soil aeration, thereby accelerating microbial breakdown of organic matter (Gal et al. 2007; Cookson et al. 2008; La Scala et al. 2008). This effect was seen only in Pittsburgh because of its initial, high organic matter levels, although a similar trend also was seen in Boston. It is hypothesized that the addition of organic matter and mulch in the full AFM process served to offset enhanced decomposition associated with air tillage.

\section{Soil Nutrients}

Overall, the AFM treatment was more successful at improving soil fertility than the F treatment, in which the same granular ma- terials were applied to the soil surface. Subsurface incorporation of fertilizer into the upper soil layers has been recommended for low solubility minerals or when roots are not present near the soil surface (Harris et al. 2004). However, Gilman et al. (2000) reported that subsurface applications provided no greater growth benefit than surface applications, a conclusion later echoed by Struve (2002). It is likely that compost and mulch added during the AFM process also contributed to soil fertility through its own decomposition and through adsorption and complexation of mineral nutrients. Materials applied to the soil surface in the $\mathrm{F}$ treatment may have been lost to run-off on compacted soils and to rapid infiltration of water in sandy soils. Whether these increases in specific nutrients are ecologically relevant to tree performance depends upon a number of factors, particularly the presence of pre-existing tree nutrient deficiencies.

Myrtle Beach was the exception to the trend of greater soil fertility with AFM. At this site, applying fertilizer to the surface was more effective than incorporating it into the soil. This result likely reflects rapid rates of nutrient leaching in sandy soil; leaching may have been accelerated by placing the fertilizer materials deeper in the soil profile in the AFM treatment.

\section{Soil Water Content}

Averaged across all dates, soil water content in Anderson, South Carolina was 31\% higher in mulched plots (M and AFM) than in unmulched plots (control, A, and F). During periods of intense drought, the soil water content of mulched plots was as much as $61 \%$ higher than that of unmulched plots. Reduced evaporation and increased soil water content are well-known benefits of mulching in a variety of soil types and landscapes (Smith and Rakow 1991; Greenly and Rakow 1995; Singer and Martin 2008; but see Arnold et al. 2005). Mulch also reduces competition for water by limiting weed germination and growth

Table 4. Soil pH and nutrient concentrations beneath red maple (Acer rubrum) trees at four urban sites in the eastern United States in spring 2008. Within a site and column, means followed by different letters are significantly different (SAS PROC GLIMMIX, Fisher's LSD $P<0.05$ ). For treatment descriptions, see Materials and Methods.

\begin{tabular}{|c|c|c|c|c|c|c|c|c|c|c|}
\hline Site & Treatment & $\mathrm{pH}$ & $\begin{array}{l}\mathrm{P} \\
\text { (kg/ha) }\end{array}$ & $\begin{array}{l}\mathrm{K} \\
\text { (kg/ha) }\end{array}$ & $\begin{array}{l}\mathrm{Ca} \\
(\mathrm{t} / \mathrm{ha})\end{array}$ & $\begin{array}{l}\mathrm{Mg} \\
\text { (kg/ha) }\end{array}$ & $\begin{array}{l}\mathrm{Zn} \\
\text { (kg/ha) }\end{array}$ & $\begin{array}{l}\text { Mn } \\
\text { (kg/ha) }\end{array}$ & $\begin{array}{l}\mathrm{Cu} \\
(\mathrm{kg} / \mathrm{ha})\end{array}$ & $\begin{array}{l}\mathrm{B} \\
(\mathrm{kg} / \mathrm{ha})\end{array}$ \\
\hline \multirow[t]{4}{*}{ Anderson } & $\mathrm{C}$ & $6.1 \mathrm{bc}$ & $12.3 b$ & $220.3 b$ & $1.2 \mathrm{~b}$ & $146.5 \mathrm{c}$ & $3.8 \mathrm{~b}$ & $51.0 \mathrm{a}$ & $2.4 \mathrm{ab}$ & $0.7 b$ \\
\hline & AFM & $6.6 \mathrm{a}$ & $22.8 \mathrm{a}$ & $302.0 \mathrm{a}$ & $1.9 \mathrm{ab}$ & $363.3 \mathrm{a}$ & $6.5 \mathrm{a}$ & $55.7 \mathrm{a}$ & $3.0 \mathrm{a}$ & $1.3 \mathrm{ab}$ \\
\hline & $\mathrm{F}$ & $5.9 c$ & $8.7 b$ & $216.8 b$ & $1.2 \mathrm{~b}$ & $158.6 \mathrm{c}$ & $3.5 b$ & $55.6 \mathrm{a}$ & $2.2 \mathrm{ab}$ & $0.7 b$ \\
\hline & M & $6.3 \mathrm{ab}$ & $7.7 b$ & $233.1 b$ & $2.6 \mathrm{a}$ & $204.7 b$ & $4.0 \mathrm{~b}$ & $61.6 \mathrm{a}$ & $1.6 \mathrm{~b}$ & $1.8 \mathrm{a}$ \\
\hline \multirow[t]{4}{*}{ Boston } & $\mathrm{C}$ & $5.5 b$ & $157.0 \mathrm{~b}$ & $169.1 \mathrm{a}$ & $1.7 \mathrm{bc}$ & $182.9 \mathrm{~b}$ & $10.3 b$ & $35.7 b$ & $5.9 \mathrm{a}$ & $0.3 b$ \\
\hline & A & $5.5 b$ & $182.9 \mathrm{~b}$ & $199.7 \mathrm{a}$ & $1.6 \mathrm{c}$ & $169.3 b$ & $11.2 \mathrm{~b}$ & $30.5 b$ & $4.9 \mathrm{a}$ & $0.3 b$ \\
\hline & $\mathrm{F}$ & $5.6 \mathrm{~b}$ & $177.9 \mathrm{~b}$ & $179.4 \mathrm{a}$ & $1.9 \mathrm{bc}$ & $187.3 \mathrm{~b}$ & $11.2 \mathrm{~b}$ & $35.2 b$ & $5.9 \mathrm{a}$ & $0.3 b$ \\
\hline & M & $5.6 \mathrm{~b}$ & $131.9 \mathrm{~b}$ & $122.5 b$ & $2.0 \mathrm{~b}$ & $205.4 \mathrm{~b}$ & $11.8 \mathrm{~b}$ & $39.9 b$ & $3.6 \mathrm{a}$ & $0.3 b$ \\
\hline \multirow[t]{4}{*}{ Myrtle Beach } & $\mathrm{C}$ & 7.0ab & $55.2 \mathrm{a}$ & $74.3 \mathrm{a}$ & $4.8 \mathrm{a}$ & $91.7 b$ & $2.8 \mathrm{~b}$ & $10.9 \mathrm{~b}$ & $2.0 \mathrm{a}$ & $0.6 \mathrm{a}$ \\
\hline & AFM & $6.5 b$ & $33.7 \mathrm{~b}$ & $86.2 \mathrm{a}$ & $6.0 \mathrm{a}$ & $173.9 \mathrm{a}$ & $4.1 \mathrm{ab}$ & $28.8 \mathrm{a}$ & $0.4 \mathrm{a}$ & $0.7 \mathrm{a}$ \\
\hline & A & 7.1ab & $50.2 \mathrm{ab}$ & $78.6 \mathrm{a}$ & $5.4 \mathrm{a}$ & $124.3 \mathrm{ab}$ & $3.4 \mathrm{ab}$ & $11.6 \mathrm{~b}$ & $1.5 \mathrm{a}$ & $0.6 \mathrm{a}$ \\
\hline & $\mathrm{F}$ & $6.8 \mathrm{ab}$ & $45.0 \mathrm{ab}$ & $96.4 \mathrm{a}$ & $5.9 \mathrm{a}$ & $118.5 \mathrm{ab}$ & $4.8 \mathrm{a}$ & $27.9 \mathrm{a}$ & $1.1 \mathrm{a}$ & $0.6 \mathrm{a}$ \\
\hline \multirow[t]{5}{*}{ Pittsburgh } & $\mathrm{C}$ & $6.0 \mathrm{~b}$ & $70.3 b$ & 266.1a & $3.6 \mathrm{a}$ & $333.9 b$ & $13.0 \mathrm{a}$ & $55.8 \mathrm{c}$ & $2.2 \mathrm{ab}$ & $1.1 \mathrm{~b}$ \\
\hline & AFM & $5.7 \mathrm{~b}$ & $112.1 \mathrm{a}$ & $275.7 \mathrm{a}$ & $4.5 \mathrm{a}$ & $323.1 \mathrm{bc}$ & $10.5 \mathrm{ab}$ & 83.6ab & $1.8 \mathrm{ab}$ & $1.2 \mathrm{ab}$ \\
\hline & A & $6.2 b$ & $110.7 \mathrm{a}$ & $257.5 \mathrm{a}$ & $3.6 \mathrm{a}$ & $398.5 \mathrm{ab}$ & $6.5 \mathrm{c}$ & $42.6 \mathrm{c}$ & $1.7 \mathrm{~b}$ & $1.0 \mathrm{~b}$ \\
\hline & $\mathrm{F}$ & $4.8 \mathrm{c}$ & $67.5 \mathrm{~b}$ & $176.6 \mathrm{~b}$ & $3.6 \mathrm{a}$ & $216.6 c$ & $8.2 b c$ & $94.2 \mathrm{a}$ & $3.7 \mathrm{a}$ & $0.4 \mathrm{c}$ \\
\hline & M & $7.0 \mathrm{a}$ & $91.5 \mathrm{ab}$ & $306.4 \mathrm{a}$ & $5.7 \mathrm{a}$ & $460.0 \mathrm{a}$ & $6.6 c$ & $58.4 \mathrm{bc}$ & $0.9 \mathrm{~b}$ & $1.6 \mathrm{a}$ \\
\hline
\end{tabular}


(Abouziena et al. 2008). In related work, the study authors have recorded that trees growing in AFM and M soil had maintained higher pre-dawn water potentials during periods of intense drought (unpublished data), indicating that higher soil moisture translated directly into higher tree water status at this site.

\section{CONCLUSIONS}

A program of air tillage, prescription fertilization, and mulch improved a suite of physical and chemical properties in urban soils. Mulch was the most effective of the individual treatments, increasing soil organic matter and water content as effectively as the full AFM treatment and providing short-term decreases in soil strength. The specific benefits of the AFM treatment differed by site. In the field, practitioners should experiment with specific materials, techniques, and treatment frequencies to best address the needs of individual sites. Nonetheless, it is clear that a multipronged approach to soil remediation gives arborists an effective means to improve compacted soils beneath established urban trees.

\section{LITERATURE CITED}

Abouziena, H.F., O.M. Hafez, I.M. El-Metwally, S.D. Sharma, and M. Singh. 2008. Comparison of weed suppression and mandarin fruit yield and quality obtained with organic mulches, synthetic mulches, cultivation, and glyphosate. Hortscience 43:795-799.

Alberty, C.A., H.M. Pellett, and D.H. Taylor. 1984. Characterization of Soil Compaction at Construction Sites and Woody Plant Response. Journal of Environmental Horticulture 2:48-53.

Arnold, M.A., G.V. McDonald, and D.L. Bryan. 2005. Planting depth and mulch thickness affect establishment of green ash (Fraxinus pennsylvanica) and bougainvillea goldenraintree (Koelreuteria bipinnata). Journal of Arboriculture 31:163-170.

Cookson, W.R., D.V. Murphy, and M.M. Roper. 2008. Characterizing the relationships between soil organic matter components and microbial function and composition along a tillage disturbance gradient. Soil Biology \& Biochemistry 40:763-777.

Daddow, R.L., and G.E. Warrington. 1983. Growth-limiting soil bulk densities as influenced by soil texture. Watershed Systems Development Group report. USDA Forest Service. Fort Collins, CO. pp. 1-17.

Day, S.D., and N.L. Bassuk. 1994. A review of the effects of soil compaction and amelioration treatments on landscape trees. Journal of Arboriculture 20:9-16.

Department of Environment and Climate Change NSW. 2007. Using Compost Materials on Council Sporting Fields. ISBN 978174122 391 0. Sydney, New South Wales, Australia.

Fraedrich, S.W., and D.L. Ham. 1982. Wood chip mulching around maples: Effect on tree growth and soil characteristics. Journal of Arboriculture 8:85-89.

Gal, A., T.J. Vyn, E. Micheli, E.J. Kladivko, and W.W. McFee. 2007. Soil carbon and nitrogen accumulation with long-term no-till versus moldboard plowing overestimated with tilled-zone sampling depths. Soil \& Tillage Research 96:42-51.

Gilman, E.F., T.H. Yeager, and D. Kent. 2000. Fertilizer rate and type impacts magnolia and oak growth in sandy landscape soil. Journal of Arboriculture 26:177-182.

Greenly, K.M., and D.A. Rakow. 1995. The effect of wood mulch type and depth on weed and tree growth and certain soil parameters. Journal of Arboriculture 21:225-232.
Harris, R.W., J.R. Clark, and N.P. Matheny. 2004. Arboriculture Integrated Management of Landscape Trees, Shrubs, and Vines. Fourth Edition. Pearson Education, Upper Saddle River, New Jersey.

Janoo, B.V., A.J. Firicano, L.A. Barna, and S.A. Orchino. 1999. Field testing of stabilized soil. Journal of Cold Regions Engineering March: 37-53.

Kalisz, P.J., J.W. Stringer, and R.J. Wells. 1994. Vertical mulching of trees: Effects on roots and water status. Journal of Arboriculture $20: 141-145$

La Scala, N., A. Lopes, K. Spokas, D. Bolonhezi, D.W. Archer, and D.C. Reicosky. 2008. Short-term temporal changes of soil carbon losses after tillage described by a first-order decay model. Soil Tillage and Research 99:108-118.

Mirreh, H.F., and J.W. Ketcheson. 1972. Influence of bulk density and matric pressure to soil resistance penetration. Canadian Journal of Soil Science 52:477-483.

Moore, K. Soil Lab Methods. 2010. Clemson University Agricultural Service Laboratory. Accessed 09/14/2010. <www.clemson.edu/public/regulatory/ag_svc_lab/soil_testing/soil_procedures/index.html>

Pabin, J., J. Lipiec, S. Wlodek, A. Biskupski, and A. Kaus. 1998. Critical soil bulk density and strength for pea seedling root growth as related to other soil factors. Soil and Tillage Research 46:203-208.

Rolf, K. 1994. Soil compaction and loosening effects on soil physics and tree growth. In: G.W. Watson and D. Neely (Eds.). The Landscape Below Ground. International Society of Arboriculture, Savoy, IL.

Singer, C.K., and C.A. Martin. 2008. Effect of landscape mulches on desert landscape microclimates. Arboriculture \& Urban Forestry 34:230-237.

Smiley, E.T. 1994. The effects of soil aeration equipment on tree growth. In: G.W. Watson and D. Neely (Eds.). The Landscape Below Ground. International Society of Arboriculture, Savoy, IL.

Smiley, E.T. 2001. Terravent: Soil fracture patterns and impact on bulk density. Journal of Arboriculture 27:326-329.

Smiley, E.T., G.W. Watson, B.R. Fraedrich, and D.C. Booth. 1990. Evaluation of soil aeration equipment. Journal of Arboriculture 16:118 123

Smith, A.M., and D.A. Rakow. 1991. Strategies for reducing water input in woody landscapes. Journal of Arboriculture 18:165-170.

Smith, E.M. 1978. Fertilizing trees and shrubs in the landscape. Journal of Arboriculture 4:157-161.

Sojka, R.E., W.J. Busscher, and G.A. Lehrsch. 2001. In situ soil strength, bulk density and water content relationships of a durinodic xeric haplocalcid soil. Soil science 166:520-529.

Struve, D.K. 2002. A review of shade tree nitrogen fertilization research in the united states. Journal of Arboriculture 28:252-261.

Tan, K.H. 1996. Soil Sampling, Preparation, and Analysis. Marcel Dekker, Inc., New York, NY.

Waltz, C., S. Burnett, V. Quisenberry, and B. McCarty. 2000. Soil amendments affect compaction, soil strength. Golf Course Management 68:49-55.

Watson, G.W. 2002. Soil replacement: Long-term results. Journal of Arboriculture 28:229-230.

Watson, G.W. 1988. Organic mulch and grass competition influence tree root development. Journal of Arboriculture 14:200-203.

Watson, G.W., P. Kelsey, and K. Woodtli. 1996. Replacing soil in the root zone of mature trees for better growth. Journal of Arboriculture 22:167-172. 
Kelby L. Fite

Arboricultural Researcher

Bartlett Tree Research Laboratories

13768 Hamilton Road

Charlotte, NC 28278, U.S.

\section{E. Thomas Smiley}

Arboricultural Researcher

Bartlett Tree Research Laboratories

13768 Hamilton Road

Charlotte, NC 28278, U.S.

John McIntyre

Graduate Assistant

Department of Horticulture

Clemson University

Clemson, SC 29634-0319, U.S.

Christina E. Wells (corresponding author)

Assistant Professor

Department of Horticulture

Clemson University

Clemson, SC 29634-0319, U.S.

Résumé. Les effets du processus de décompaction avec amendement du sol, ainsi que ceux de ses composantes individuelles (labour/binage, fertilisation, paillis), sur les propriétés du sol ont été analysés dans quatre sites urbains des États-Unis: Anderson (Caroline du Sud), Boston (Massachusetts), Myrtle Beach (Caroline du Sud) et Pittsburgh (Pennsylvanie). Dans chacun des sites, 50 érables rouges (Acer rubrum) qui poussaient déjà dans des sols compactés et/ou pauvres en éléments minéraux et qui avaient une densité entre 1,14 et $1,74 \mathrm{~g} / \mathrm{cm}^{3}$ ont été choisis. Les traitements ont été appliqués durant l'automne et l'hiver 2005-2006, et les mesures ont été prises jusqu'à la fin de 2008. Les traitements de décompaction avec amendement ont permis de réduire significativement la résistance relative du sol par rapport aux unités-témoin, et ce pour tous les sites en 2006. Il y avait des interactions significatives entre les divers traitements et les divers emplacements durant toutes les années, et les sites qui avaient les sols les plus denses (Anderson et Mrytle Beach) démontraient les réponses les plus grandes en magnitude et en durée. La décompaction avec amendement, ainsi que la pose de paillis, permettaient généralement d'accroître le contenu du sol en matière organique, tandis que le labour/binage seul diminuait significativement ce contenu à Pittsburgh. Dans la plupart des sites, la décompaction avec amendement était plus efficace que l'application en surface d'engrais pour améliorer la fertilité du sol. Les unités avec décompaction et amendement, ainsi que celles avec paillis, avaient un contenu en eau significativement plus élevé que les autres unités durant les périodes de sécheresse estivale. Globalement, la décompaction avec amendement était efficace pour améliorer les conditions de sol sous des arbres déjà établis, et le paillis le plus efficace parmi les divers traitements évalués individuellement.

Zusammenfassung. Die Auswirkungen einer Bodenlockerung und eines Düngungsprozesses (AFM) und deren individuellen Komponenten (Belüftung, Dünger und Mulch) auf Bodenverhältnisse wurden an vier urbanen Standorten: Anderson, SC; Boston, MA; Myrtle Beach, SC; und Pittsburgh, PA untersucht. An jedem Standort wurden 50 Rotahorne auf verdichtetem und/oder nährstoffarmen Boden, deren Substratdichte vor der Behandlung zwischen 1,14 bis $1,74 \mathrm{~g} / \mathrm{cm}^{3}$ betrug, gezogen. Die Behandlungen wurden im Herbst und Winter 2005/06 durchgeführt und die Messungen wurden am Ende von 2008 erhoben. Die AFM-Behandlung reduzierte an allen Standorten in 2006 deutlich die Bodenstärke in Relation zur Kontrolle. Es gab in allen Jahren deutliche Behandlung versus Standort Interaktionen, wobei die Standorte mit höherer Bodendichte
(Anderson und Myrtle Beach) die größte Magnitude und Dauer der Resonanz zeigten. Die AFM und Mulch-Behandlungen vergrößerten allgemein den Anteil an organischer Masse, während die Belüftung allein die Bodenverdichtung in Pittsburgh senkte. An den meisten Standorten war die AFM-Behandlung effektiver in der Verbesserung der Bodenfruchtbarkeit als die Oberflächenapplikation vonDünger. AFM und gemulche Standorte hatten einen deutlich höheren Wasseranteil als andere Standorte während der sommerlichen Trockenperioden. Im großen und ganzen war AFM sehr effektiv imVerbessern von Böden unterhalb etablierter Bäume und Mulchen erwies sich als die beste unter den individuellen Behandlungen.

Resumen. Los efectos de la descompactación del suelo y procesos de mejoramiento (AFM) y sus componentes individuales (aireación del suelo, fertilización y mulch) en las propiedades del suelo fueron investigados en cuatro sitios urbanos: Anderson, SC; Boston, MA; Myrtle Beach, SC; y Pittsburgh, PA. En cada sitio, estuvieron creciendo 50 maples rojos (Acer rubrum) en suelos compactados y/o pobres en minerales cuyas densidades variaron de 1.14 a $1.74 \mathrm{~g} / \mathrm{cm} 3$. Los tratamientos fueron aplicados en el otoño e invierno de 2005-2006, y las mediciones fueron tomadas a través del 2008. El tratamiento AFM redujo significativamente la compactación del suelo en comparación a los controles en 2006. Hubo interacciones significantes tratamiento $\mathrm{x}$ localidad en todos los años, con las más altas densidades reales (Anderson y Myrtle Beach) mostrando la mayor magnitud y duración de respuesta. El AFM y los tratamientos de mulch generalmente incrementaron el contenido de materia orgánica del suelo, mientras que la aireación del suelo solamente bajó significativamente en Pittsburgh. En la mayoría de los suelos, el tratamiento AFM fue más efectivo que la aplicación superficial de fertilizante en el mejoramiento de la fertilidad del suelo. AFM y parcela con mulch significativamente tuvieron contenido de agua en el suelo más alto que otras parcelas durante los períodos de sequía de verano. En resumen, AFM fue efectivo en mejoramiento de suelos con árboles establecidos, y el mulching fue el más benéfico de los tratamientos individuales. 